\title{
Journalistic Slanting Of the Governor Chris Ngige and Chris Uba Prebendal Political Conflict in South-Eastern Nigeria, 2004-2006
}

\section{Muyiwa Popoola*}

Department of Communication and Media Studies, Ajayi Crowther University, P.M.B. 1066, Oyo town Oyo State, Nigeria

\begin{abstract}
Prebendal political conflicts are crises of the ruling and political class, owing to disagreement in respect of appropriation and sharing of resources and wealth of a nation state, as personal needs and entitlements, Prebendalism, which is a strong concomitant of political godfatherism, has disturbed Nigeria's democracy. The period between 2004 and 2006 has recorded a ruinous prebendal political conflict in the South-Eastern geo-political zone of Nigeria. The conflict, which involved an erstwhile Governor of Anambra State, Dr. Chris Ngige and a political chieftain in the state, Chief Chris Uba, occurred with attendant violence. However, empirical studies on the role played by the press in this type of conflict situation are faint in political communication literature. This study therefore was conducted to investigate how selected newspapers reported the Ngige and Uba prebendal political conflict in South-Eastern Nigeria between 2004 and 2006. Four Nigerian national newspapers were chosen for the study, namely: Daily Champion, Daily Trust, Nigerian Tribune and The Guardian. Purposive sampling was used to select 84 journalistic genres out of 72 editions of the newspapers. The study was organized within hermeneutical framework. All the newspapers reported scenarios that aided escalation of the conflict. The coverage reflected partisanship. Most particularly, Daily Champion took side blatantly and unprofessionally with Ngige against Uba. The reportage predicted destruction of lives and properties and violent acts that were perpetrated by the supporters of the conflicting parties in Anambra State of Nigeria between 2004 and 2006. The journalistic slanting of the conflict contravenes the tenets of a socially responsible press. Newspapers in Nigeria must be socially responsible in reporting political conflicts so as to bring about a peaceful political order in the country.
\end{abstract}

Keywords: Prebendal political conflict; Journalistic slanting; Newspaper reportage; Violence

\section{Introduction and Statement of Problem}

Joseph [1] is usually credited with popularizing and using the term prebendalism to describe patron-client relationships in Nigeria. He writes: "according to the theory of prebendalism, state offices are regarded as prebends that can be appropriated by officeholders, who use them to generate material benefits for themselves and their constituents and kin groups..." Giving the antecedent to prebendalism, Joseph mentions that the first general application of the term prebend was made by Max Weber, as an ecclesiastical term signifying the stipend drawn from land and granted to a canon from a cathedral estate. Weber, according to Joseph, used this to mean "allowances in kind" or right to use of land and services where these allowances or rights are not granted on hereditary principles. Joseph [1] draws insight from Weber's morphological approach. He expands the framework for understanding prebendalism thus:

A prebendal system will be seen not only as one in which the offices of state are allocated and then exploited as benefices by the office-holders, but also as one where such a practice is legitimated by a set of political norms according to which the appropriation of such offices is not just an act of individual greed or ambition but concurrently the satisfaction of the short-term objectives of a subset of the general population.

Buttressing this point, Joseph explains that prebendalism refers to "patterns of political behavior which reflect as their justifying principle that the offices of existing state may be competed for, and then utilized for the personal benefit of office-holders as well as that of their reference or support group". He applies that to what happens in Nigeria's democracy and consequently describes Nigerian politics as being essentially "the process of gaining control of public resources for private ends". Amplifying this point, Corruption Perceptions Index Report [2] deplores this form of patronage as one aspect of "the abuse of public roles or resources for private benefit" (Table 1). Seemingly, in consonance with this view, Dike [3] notes that this type of corruption is widespread in most non-democratic countries and particularly, in countries that have been branded 'neo-patrimonial, kleptocratic and prebendal' (Figures 1 and 2).

The phenomenon has become particularly highly developed, entrenched and destructive in Nigeria. Joseph [1], in Albert, investigated the extra-legal activities of ethnic groups in Nigeria in order to capture state power. What were captured in this case included appointments into important political positions, employment opportunities, fund for developmental purposes, and educational opportunities, among others. The strategies used for capturing the state power were clientele in nature. It is in this respect that he described clientelism, often referred to as 'patron-client relations ties', as an essential tool for advancing prebendal politics. His work focuses on perceiving prebendal politics from the perspective of attainment and use of public office as a reward for loyalty to a lord or ruler. Shedding further light on the nature of prebendal politics, Joseph observes that an individual seeks out patrons as he or she moves upward socially and materially; such individuals also come to accept ties of solidarity from their own clients which they view as fundamental to the latter's security and continued advancement

*Corresponding author: Muyiwa Popoola, Department of Communication and Media Studies, Ajayi Crowther University, P.M.B. 1066, Oyo town, Oyo State, Nigeria, Tel: 0814-592-0637; E-mail: popsonbaba@yahoo.com

Received June 26, 2014; Accepted August 28, 2014; Published September 04 2014

Citation: Popoola M (2014) Public(s): Journalistic Slanting Of the Governor Chris Ngige and Chris Uba Prebendal Political Conflict in South-Eastern Nigeria, 20042006. J Mass Communicat Journalism 4: 218. doi:10.4172/2165-7912.1000218

Copyright: (c) 2014 Popoola M. This is an open-access article distributed under the terms of the Creative Commons Attribution License, which permits unrestricted use, distribution, and reproduction in any medium, provided the original author and source are credited. 


\begin{tabular}{|c|c|c|c|c|c|}
\hline Year & Rank & Country & CPI 2004 Score & Confidence Range & Surveys Used \\
\hline 2004 & 144 & Nigeria & 1.6 & $1.4-1.8$ & 9 \\
\hline 2005 & 152 & Nigeria & 1.9 & $1.7-2.0$ & 9 \\
\hline 2006 & 142 & Nigeria & 2.2 & $2.0-2.3$ & 7 \\
\hline
\end{tabular}

Table 1: Corruption Perceptions Index from 2004-2006.

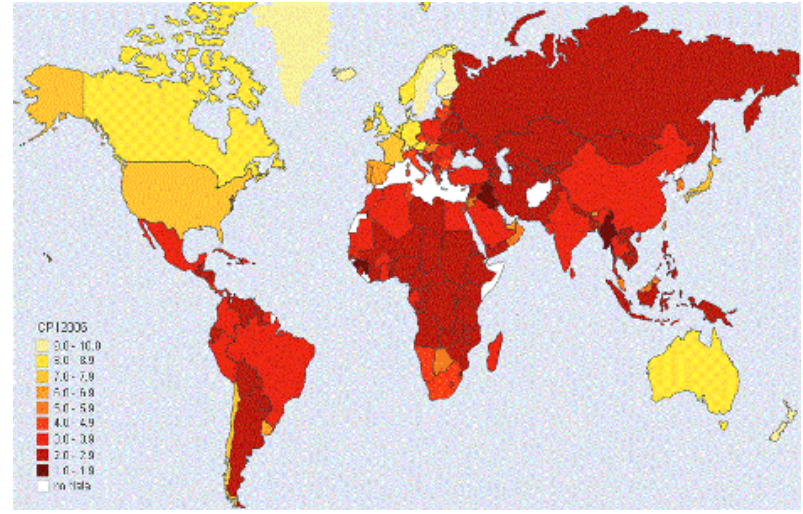

Figure 1: Corruption Perceptions Index-2006

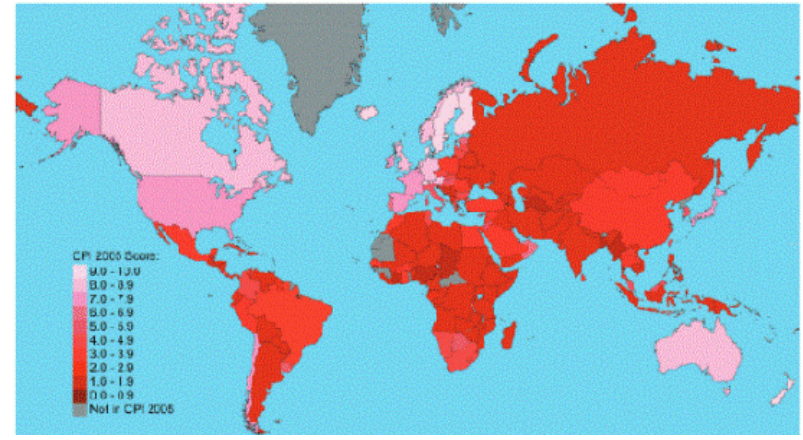

Figure 2: Corruption Perceptions Index-2005

as well as their own. Relating this to what happens on the Nigerian political scene, Albert [4] reiterates that it is a common practice in Nigeria for individuals to seek the support and protection of "an oga" (master) or a "godfather", while trying to acquire the basic social and material goods, and this kind of political behaviour manifests itself not only in the allocation of state resources but also in the private sector. The difference between these godsons and their godfathers is that the latter have 'a piece of the state' in their pockets, while the former seeks a piece of the state. The power of the godfather lies in his position in government, the number of privileged people he has or has successfully planted in government, and hence his ability to directly or indirectly manipulate bureaucratic regulations.

Supporting this assertion, Idemudia, in Omu and Oboh [5] documents that the Nigerian political environment is highly monetized; it is a cash and carry politics. Politics at all levels are infested with the money syndrome. Winning party nomination, is either by being the party 'sacred cow' backed by a 'godfather' who picks his preferred candidate through arbitrary nomination or through party primary elections which the godfather teleguides. Even a councillor, who is the lowest placed in the political position hierarchy, could need as much as 10 million naira to win party nomination aside from the general elections. This amount would lend itself to an exponential expansion when higher-level political position is sought. As the general election is sought, the battle is just beginning. The victorious politician at the polls assumes office and strategizes how to recover his expenditure, and to start the mission of homage paying to his godfather(s). Consequently, prebendalism finds expression in politics of sponsorship to political positions, control of political power, political patronage and the ultimate control of state treasury, personnel and resources. Obviously and evidently, closely knitted to prebendalism is the issue of political godfatherism.

The two phenomena appear as two sides of the same coin as evident in how political godfatherism has been conceptualized by scholars. According to Awowede [6], "the idea of godfatherism must have had its origin in the pre - christian era". In consonance with this statement, Akin [7] says "It was popularized by the Christian tradition of baptism, which requires, among other things, that an entrant into the faith should have a sponsor who undertakes to oversee his moral and spiritual welfare in line with the baptismal promise". This implies that godfatherism is not just a recent occurrence but has existed for a very long time Okoli [8] seems to have broadened the scope of godfatherism. He states:

Godfatherism does not only imply an instrument of Christian guardianship; it also connotes a system of socio - political mentorship and apprenticeship of varying sorts. In contemporary Nigeria, the phenomenon of godfatherism has veered in partisan relations, manifesting in the fashion of politics of sponsorship and apprenticeship.

Godfatherism appears to have pervaded the Nigerian political scene and this situation seems to have provoked scholarly works and empirical investigations on godfatherism with a view to gaining insight into it. In his exposition of the concept from a political perspective, Okoli [8], labels godfatherism as a form of landlord-tenant relationship between the godfathers and godsons. In this context, the godfather acts as the power broker because he can deploy his political and commercial influence to affect policies and the decision of others. The implication of this is that although there is a relationship between the godfather and godson, the godfather manipulates the policies of others in order to ensure that the person (godson) of his choice is elected. Ajayi [9] amplifies this view by observing that: "when individuals, groups or parties throw their financial weight behind a candidate seeking elective position, we see at once, the emergence of the godfather phenomenon". Lending a supporting voice, the Newswatch magazine in its editorial of August 26, 2002, states, among others:

....The godfather has the influence and affluence, the visibility and credibility to get the political godson in office. He goes round with the candidate, raises his hand at campaign rallies as evidence that that is the anointed candidate. The anointed candidate obeys his every command and sometimes both enter into a written agreement of how the spoils of victory will be shared. This may be in the form of sharing offices, or contracts or money straight from the treasury.

Consequently, politics of godfathers involves the 'anointing' of a godson who is expected to win an election by using the influence, wealth, political structure and political experience of the godfather. In return, the godson reciprocates with loyalty and regular consultations with the godfather. Adeoye [10] lends support to this paradigm that: "a godfather is a kingmaker, boss, mentor, and principal, while godson is the beneficiary and recipient of the legacy of a godfather. A godfather is someone who has built unimaginable respect and followers (voters) in the community, and possessed a well-organized political platform and general acceptance from electorate that could 
secure victory for candidates of his choice". Thus, political godfathers are powerful individuals who determine "who, what, when and how" in the corridors of power. Based on the practice of prebendalism, of which political godfatherism is a concomittant therefore, it follows that there will be cooperation and unity among political actors and political office holders when they appropriate and share resources and wealth of a nation state, as personal needs and entitlements, without any disagreement, even at the expense of the ruled. But, when there are clashes of prebendal needs and interest, direct consequences are prebendal political conflicts with attendant civil unrest. In Nigeria, there have been occurrences of prebendal political conflict, particularly in Anambra State, in the South-Eastern geo-political zone, which thwarted democratic governance in the State.

According to Popoola [11] a review of scholarly works and research findings with respect to reportage of political conflicts by Nigerian newspapers shows that newspapers in Nigeria, not largely practicing ethical journalism, have been reporting political conflicts in the country. In political struggles, contestations and machinations in the country, Nigerian newspapers have been linked with escalation of political conflicts. Nevertheless, there has been a dearth of studies in respect of the role of the Nigerian press in recognizing and characterizing prebendal political conflict as a particular type of disastrous conflict in Nigeria. Consequently, this study was conducted to fill that gap in political communication literature by investigating how selected newspapers reported the prebendal political conflict between a former governor of Anambra State, Chris Ngige and Chief Chris Uba, a political chieftain in the state, in the South-Eastern Nigeria between 2004 and 2006.

\section{The Ngige-Uba Feud: Historical incursion}

A wealthy member of the powerful Uba political family in Anambra State of Nigeria, Chris Uba, is an iconic example of the godfather phenomenon in Nigeria. Tracing the emergence of Ngige, a former governor of Anambra State, on the political scene, Okereke [12] writes that the advent of the Fourth Republic saw the emergence of Dr. Chris Nwabueze Ngige in the Anambra governorship elections. According to Okereke, Ngige was a reflection of an insidious power-play, the script of which was written in Aso Rock, and put on stage with the aid of a godfather called Chris Uba. Elaborating on this, Albert [4] writes that Dr Chris Ngige's ambition during the 2003 elections was to become a Senator, having lost in his first bid for the position in 1999. He soon came in contact with Chief Uba, who pledged to make him a governor and not just a senator. Ngige was said to have rejected the offer initially, citing the risks, the money involved and the tradition of political violence in Anambra State as his excuse. Uba assured Ngige of all the necessary support, and encouraged him to accept the nomination. $\mathrm{He}$ provided Ngige with all that was needed to become the governor of the state. Uba assured his candidate of victory but bargained hard with him. Part of the agreement reached with Ngige was that Uba would nominate seven out of the ten commissioners in the state if Ngige won the election and that he (Uba) would identify the juicy ministries to be manned by his commissioners. Ngige won the election and it became the first time an individual single handedly put in position every politician in a state. The state governor and his deputy; the 3 Senators to represent the state at the National Assembly; I0 out of 11 members of the Federal House of Representatives; and 29 State House of Assembly members. Not long after the victory, relations between Ngige and Uba deteriorated rapidly. The prebendal cum godfatherson political conflict between Ngige and Uba started when the latter started making efforts to take over Anambra state from the governor.
The problem started immediately after Ngige was nominated at the PDP primaries, and began to gather more steam after his victory was announced after the 27th April, 2003 governorship polls. Immediately Ngige won the election, his godfather insisted on nominating all the commissioners, special advisers, personal assistants among others. Ngige did not disagree with Uba on this but on the criteria to be used in determining the appointees. Conflict between Ngige and Uba brewed up and escalated when Uba indicated strongly that he had to be privy to how state money should be spent. Uba insisted that he was not a Father Christmas, and vowed to unseat Ngige for his refusal to pay a whooping 3 billion Naira as election expenses. Uba narrates how he got disappointed in Ngige:

I have been in politics from 1999 and even before, but 2003 is the time I produced a Governor for the State. When he [Ngige] became Governor, he started playing funny. That is where we disagree, we signed before he became governor. We said that I am going to produce [appoint] six to seven Commissioners. He is going to produce [some] because he is governor already. I am going to produce more; he is going to produce lesser. I spent a lot of money to put him there but I never asked him for my money back. Ngige was trying to be smart, trying to run the government on his own. The problem is Ngige being a politician who did not invest one naira, not even one kobo, wanted to run away with everything and not even share one appointment.

Governor Chris Ngige's experience on that issue illustrates that point. He narrates:

I don't have problems with people, especially if we have an agreement whether oral or otherwise. He said he wanted to do appointments of all categories of people who will work in government from transition committee chairman and members, commissioners, special advisers. I said fine, but do me a favour; that favour is my personal staff; people who'll work in my office would be my prerogative. He said, like what? I said like confidential secretary, my press secretary and my chief staff and so on. He said ok, no problem that those ones are not the ones he's talking about. The first appointment made in this Government House was the Principal Secretary to the governor, a personal staff to the governor. Somebody was hoisted on me, a man who has never worked in the civil service before. He doesn't even know what a file looks like, not to talk about writing memos for the governor...

It was probably at the end of the above encounter that Uba decided to sack the governor. However, Okereke [12] asserts that the political logjam in Anambra state came to the public knowledge with the failed abduction of the incumbent Governor Ngige, on July 10, 2003 by Uba's faction supported by a team of policemen led by an Assistant Inspector General (AIG) of Police, Raphael Ige who claimed to be acting on orders from the presidency. Ngige was abducted, allegedly with the full compliments of officialdom. The intention, from every indication was to bundle him out of office because he had fallen out with a man of means, Uba, who made it possible for him to assume the office of a governor. According to Okereke [12], Uba's faction claimed that the Governor resigned from office and this provided the grounds for their attempt to swear in Dr. Okey Ude (the then deputy governor) as the executive governor. However, Ngige refuted the allegations claiming that the purported resignation letter was signed by him under duress in a shrine before his assumption of office and that things fell apart between him and his (Uba's) faction. Okereke [12] sheds light on this unfortunate incident. According to him, the conflict led to the exposition of some of the secret transactions between Uba (godfather) and his godson. Ngige took an oath of loyalty to Uba at a shrine in Okija, Anambra State; he (Ngige) signed three undated letters 
of resignation, first as a gubernatorial aspirant before the People's Democratic Party(PDP) primaries for governorship candidates, second as a candidate for governorship and third as one declared the winner of the 2003 governorship election. He also fatalistically submitted to allowing his political godfather to exercise largely the authority of appointing people to key positions, including the governor's personal staff. As captured by Okereke, Uba later disclosed how he worked hard to enthrone a PDP led government in Anambra State. Uba boasts: "I am the greatest godfather... because this is the first time an individual single-handedly put in position every politician in the state." However, when his conflict with Ngige over the implementation of the terms of their covenant before he adopted him as his political godson and sponsored him for the 2003 governorship election could not be resolved, he resorted to exposing the truth about Ngige's election. Uba expresses with regret:

First of all, let me express my heartfelt regret for my error and the activities involved with others in Anambra to put Ngige in power as the Governor of the State. In showing remorse, I sincerely ask for understanding and forgiveness of all our people in Anambra State and those Nigerian leaders and citizens who have been unduly affected and insulted by the Anambra issue. My mistake for which I ask for understanding stemmed from my belief that election is like a battle and since all is fair in war, I believe that the end justifies the means in an election.

The most striking and disturbing aspect of Uba's unreserved revelation of their tsunamic erosion of the election result showing that the people's mandate for the governorship of Anambra State was actually won by Mr. Peter Obi of the All Progressives Grand Alliance, (APGA), but was coercively substituted with a fake result, totally devoid of legitimacy, was expressed as follows:

We did everything possible to put Ngige in power. In the presence of the President of Nigeria, Chief Olusegun Obasanjo, I asked Dr Chris Ngige whether he actually won the election; he confirmed he did not win the election. The President drove us out, as from that point, he did not want to listen to our story again. At another occasion soon after that, I had the opportunity, when Chief Audu Ogbeh invited Dr Chris Ngige and myself to his house to tell the same story. Again Dr Chris Ngige confirmed before Chief Audu Ogbeh that he did not win the election, when I asked him the same question. Because he was more attentive than the President, I told him that even the certificate of return of the Governorship election was in my custody and at the appropriate time I will make the copies available to the press. Chief Audu Ogbeh advised that we should all keep quiet on the issue of Governorship Election in Anambra. I obeyed.

Okereke [12] interprets this situation as he recalls that, at that time, Chief Audu Ogbeh was the National Chairman of the People's Democratic Party (PDP) and that it was ironical that Uba was in custody of Ngige's certificate of return. That was a practical demonstration that Ngige was his puppet. Furthermore, the reported reactions of President Obasanjo and Chief Ogbeh to the confession that Ngige had no legitimate authority to exercise Anambra State people's mandate as governor left much to be desired. In fact, they declined from boldly setting in motion a course of action that would enable Mr. Peter Obi to regain his mandate. Ngige, therefore, remained in office illegitimately until he was flushed out of office in March 2006 by the Court of Appeal sitting in Enugu.

\section{Research questions}

Based on the articulated problem of this study, the following research questions were put forward to serve as guide for the study:

- How did selected newspapers slant the reportage of the conflict?

- To what extent was the slanting in adherence to the tenets of a socially responsible press?

\section{Limitations of the study}

The focus of this study was the journalistic slanting of prebendal political conflict between Ngige and Uba in the South-Eestern geopolitical zone in Nigeria within the period of 2004 and 2006 when the conflict escalated into civil unrest in Anambra State. Four nationally circulated newspapers were chosen for the study, and they included: Daily Champion, Daily Trust, The Guardian and The Punch. Selection of these newspapers was based on a number of reasons. First, according to Popoola [11] it is logical to assume that any conflict involving individuals at the top hierarchy of government in federalism, such as Nigeria, would have implications for national development. Hence, newspapers to be chosen in this respect have to be national in their spread and circulation. This is the first rationale behind the choice of the newspapers which are rated as national newspapers by the Audit Bureau of Circulation (ABC), Nigeria Union of Journalists (NUJ), Nigeria Guild of Editors (NGE) and Nigeria Press Council (NPC). Also, the ownership identity of the founders of the newspapers was another factor that prompted the choice of the newspapers. This was to ascertain if there was any relationship between ownership of each of the newspapers and the slant of the reportage of the conflicts. The study was also thwarted by other limitations. One is that it was not possible to sample all the editions of the selected newspapers with regards to how they slanted the conflict, owing to the reason that the data to be gathered would be too enormous to manage and discuss if all the editions were included in the sample. Also, if all the editions of the newspapers were sampled, there were possibilities that some editions might not carry editorial items needed for analysis. Thus, a sample of editions that carried editorial items needed for analysis was drawn for the study.

\section{Methodology}

The study used the dialectical hermeneutics style of textual analysis in data gathering and analysis. This method was adopted for the study because it is used by cultural studies researchers to interpret textual matters with a view to bringing out possible intentions of the writers of such text. This method was suitable for this study as it made it practically possible to interpret the intentions, opinions and dispositions of the selected newspapers. Thus, subjective analysis was pivotal to the study especially for ascertaining the ways by which selected newspapers slanted their reportage of the conflict, and also bringing out the actual role played by the newspapers in the escalation or de-escalation of the conflict, as might be substantiated largely, the method was used to determine how adherent or otherwise was the slanting of the reportage to the tenets of a socially responsible press.

\section{Sample and sampling procedure}

The sample size for this study was 72 editions of the four newspapers. Breaking this down, 18 editions of each newspaper were sampled in respect of the conflict. Systematic and purposive methods were adopted in the sampling of the editions of each of the newspapers per year for the three year frame (2004-2006). Thus, for the conflict, from a segment of two months, starting from 2004 to 2006, at least one edition of each of the newspapers was sampled, and as such 
there were at least 6 editions of each newspaper per year, and at least 18 editions of each newspaper for the three-year frame. However, in order to ensure that sampled editions were editions that carried stories on the conflict, purposive sampling was used to select editions of the newspapers that carried mainly stories on the conflict with manifest or implicit inciting contents. This was done to investigate partisanship and neutrality as reflected in the newspapers in reporting the conflict and its accompanying violence.

\section{Method of data presentation and analysis}

As stated earlier dialectical hermeneutics style of textual analysis was used for the study. Consequently, in order to generate relevant data through the use of the method, two broad content categories were devised. Subsequently, these content categories were developed in order to determine and analyze the reportage of the conflicts by the selected newspapers. The two principal content categories were:

Conflict escalatory stories: These were stories that fuelled the conflicts. Such stories increased the intensity of the conflicts and led to manifestation of the conflicts in forms of violence, destruction of lives and property and anarchy. Such stories were operationalised as:

Favourable and unfavourable stories: These were stories which contained the perspective of only one of the two conflicting parties at the expense of the other party. Such stories did not report the angle of the other party. These were stories which were slanted in support of a conflicting party and which were unfavourable to the other conflicting party.

Conflict De-escalatory stories: These were stories that exhibited the canons of socially-responsible journalism and peace journalism. The stories tended to reconcile two conflicting parties by mentioning the two perspectives and emphasizing efforts aimed at resolving the conflicts and the need for resolution of the conflicts in order to bring about peace. Such stories were operationalised as:

Resolution stories: These were stories in which the two sides of the two conflicting parties were mentioned. In such stories, efforts aimed at resolving the conflicts were reported.

The data obtained from the use of dialectical hermeneutics were thoroughly explored and analyzed to extract relevant information that are related to identified elements of the study. Both the implicit and manifest contents of the sampled newspapers were subjected to discursive and narrative analysis. The focus of analysis in the sampled newspapers was mainly political stories with manifest or implicit inciting contents.

\section{Findings}

Discussion here is aimed at providing answers to the specific research questions raised in this study.

\section{Research question 1}

How did selected newspapers slant the reportage of the conflict?

\section{Research question 2}

To what extent was the slanting in adherence to the tenets of a socially responsible press?

The data that provides answers to these questions are hereby presented and analyzed qualitatively using the dialectical hermeneutics style of textual analysis. However, in order to make the data manageable and sizeable, a few of the contents of the sampled editions of the newspapers regarding the conflict are analyzed thus:

\section{Newspaper:}

Daily Champion: Daily Champion published very inciting and incriminating statements attributed to the two conflicting parties and their respective supporters. The paper became a forum for war of words between the two parties. The reportage, as shown below, must have aggravated the conflict.

\section{They took me to a shrine-Ngige}

Embattled Governor of Anambra State, Dr. Chris Ngige yesterday told the senate that he was forced to a shrine by his 'sponsors' in order to secure his loyalty. Ngige pointedly accused his deputy. Dr. Okey Udeh and Chief Chris Uba of taking him to a local shrine in the state....(July 19, 2003, front page)

Consequently, Uba threatened to reveal the secret behind Ngige's emergence as the governor of Anambra State. It was becoming obvious that his election was rigged and sponsored by Uba and his cohorts. This found expression in the following story as the details of the conflict got messier by the day.

\section{Ngige faces fresh threat}

Like a broken family whose members would rather destroy their inheritance than share it, the Anambra crisis has taken a much more messier dimension with the group loyal to Chief Chris Uba making good its threat to "spill the beans" on how the People's Democratic Party (PDP) won the elections in the state. (20 July, 2003,Page 2)

As a response to Uba's threat to spill the beans on their erstwhile deal in government, Ngige's outburst found expression in this story:

\section{....NGIGE: "I can't be removed"}

Governor Chris Ngige of Anambra State swiftly reacted to the court injunction restraining him for performing his functions, saying it was of no effect as he is covered by constitutional immunity. He also said the recourse to seeking an injunction is a "a ploy by Chris Uba and his cotravelers in the path of destruction to escape treason trial for their role in the abduction saga. (July 23, 2003, front page)

Ngige's anger as reported by the newspaper, further escalated the conflict as it included name-calling and abusive words that served to slight the person of Uba. Perhaps, reconciliatory moves were taken to de-escalate the conflict but featuring Ngige as the unrepentant of the conflicting duo, the paper came out with a story in which Ngige gave Uba conditions for peace to reign and it was published thus:

\section{Ngige gives UBA condition for peace}

Still smarting from the July 10 abduction incident, Anambra State Governor, Dr Chris Ngige at the weekend gave a condition for reconciliation with his estranged political godfather, Chief Uba and others. He said they must allow him "to administer Anambra State unfettered and execute my programmes to the fullest". (Nov 4, 2003, front page)

Apparently, this condition did not go down well with Uba and another dimension to the conflict emerged in which Ngige started alleging threat to his life and fingering Uba as the prime suspect.

\section{UBA plans to kill me, Ngige petitions IGP}

Political crisis in Anambra State has taken another dimension with 
Citation: Popoola M (2014) Public(s): Journalistic Slanting Of the Governor Chris Ngige and Chris Uba Prebendal Political Conflict in South-Eastern Nigeria, 2004-2006. J Mass Communicat Journalism 4: 218. doi:10.4172/2165-7912.1000218

Governor Chris Ngige petitioning Inspector General of Police (IGP), Mr. Tafa Balogun over alleged attempt by his estranged godfather, Chief Chris Uba to kill him. (November 21, 2003, front page)

The way the story was presented might have created an atmosphere of tension and insecurity in the State with Ngige and Uba in the centre of the storm. This further aggravated rather than ameliorate the conflict with accusations that were violence laden while the conflicting parties kept on being suspicious of each other. Afterwards, there was a shootout between parties loyal to each of the conflicting sides at the SouthEastern congress of the party which both of them belonged to. A day after, the paper published this report on what the duo perceived to be the cause of the incident and this snowballed into them, accusing each other and the paper featured the hot, destructive, dangerous verbal exchanges further infuriating the conflict:

\section{Ngige, UBA trade blames}

Twenty-four hours after shoot-out rocked the South-East zonal congress of the People's Democratic Party (PDP) in Enugu, the two major actors in the conflict, Anambra State governor, Dr. Chris Ngige and his estranged political godfather, Chief Chris Uba, yesterday traded blames over the incident. While the governor claimed that violence at the congress was a smokescreen to mask a fresh attempt by Uba's supporters to abduct him, as a Prisoner of War (POW), Chief Uba who said he arrived the congress after the fighting, dismissed Ngige's claim, saying the shooting which he alleged was by the retinue of mobile policemen showed that " he is not fit to be governor", (Daily Champion, December 8, 2003, Front page)

In taking sides, the Anambra People's Assembly condemned the gang-up against Ngige by Uba, thus taking sides with Ngige in the conflict, and it was reported accordingly:

\section{Anambra people condemn gang-up against Ngige}

Anambra People's Assembly (APA) has condemned last Saturday's shoot-out between security agents attached to Anambra State Governor, Chris Ngige and thugs hired by the governor's chief antagonist Chief Chris Uba in Enugu. (December 11, 2003, page 5)

Following the withdrawal of his security aides, Ngige went underground, and in this, the paper helped to create a feeling of helplessness on Ngige's part, blaming Uba for his (woes) and creating anxiety and panic capable of instigating the opposing party to react to what has been published in the paper as expected of them:

\section{Travails of an embattled governor}

Last Sunday, the Governor of Anambra State, Dr Chris Ngige went underground to obviate possible assassination as being hatched by his political opponents, following the withdrawal of police security aides from him... (January 11, 2004, page 10)

To counter this support for Ngige, the paper subsequently published biased stories to attack Ngige without balancing them with those of Uba. One of such is below:

\section{Noble gangsters in Anambra}

Because Ngige by his own account wanted to be governor, no matter what, he allowed himself to be slapped multiple times and his shirt torn to smithereens. For the same purpose too, he signed away, well ahead of his coming into office, billions of naira of Anambra people's money. And just because Ngige needed just a passing mention as governor for a month, in exchange for a huge sum of money, he signed his resignation letter accordingly, and well in advance, too. Then on July 10, last year, when his resignation was enforced, he recoiled to plead that he did all that under duress. Let him tell that to the marines... (23 Jan, 2004, Inside page)

Emotional sentiments were attached to the opinion such that they served to defame and liken the person of Ngige to a beggar. It outrightly pointed accusing fingers at Ngige and this was orchestrated to whip up negative sentiments against him and celebrating such served to worsen the conflict situation.

\section{Newspaper:}

Daily Trust: A month after the abduction of Ngige, Daily Trust published a story which was aimed at absolving those who participated in the abduction of Ngige. It turned the table of the discourse over by subtly appealing to the minds of the public to whip up sentiments against Ngige rather than looking for ways to solve the problem at hand:

\section{The Ngige saga: Who is the saint?}

If it were possible for the ruling party to exhibit emotions of shame and remorse, the PDP leadership, collectively and individually, would have been hanging their heads. Not surprisingly though, all we see is grandstanding, rebuttals, double speaks, bravado,... faced lying, halftruths and mealy mouthed denials in respect of the Anambra show of shame. Dr Ngige, while all attention is focused on his abductors, is prancing around seemingly enjoying the attention and attempting to talk tough. Here is a guy, who for hunger to have a taste of a position far beyond his conception and competence, was willing to lick boots, crawl and subject himself to general all-round indignities. He jumped when Chris Uba ordered. He clucked like an hen when Chuma Nzeribe so desired.....I am talking about kicking out Chris Ngige constitutionally by Anambrans for a genuine leadership. He must not, amongst others, be allowed to benefit from the mess he helped to create willingly.... (August 6, 2003, page 7)

As a differing opinion on the issue, the paper came out with a publication to further rocket the conflict situation and posited that those behind the ordeal should be thoroughly dealt with. This gave less than sufficient attention to efforts by warring parties to make peace, or calls for dialogue or discourse on how the conflict in question might be resolved. Rather, it appears there was greater discourse on the more brutal aspects of the conflict as expressed below:

\section{A slap on Nigerians' sensibility}

There is a common adage that says that one whose work is designated to cut heads will in no circumstances permit anyone to raise cutlass above his head..... All animals are equal, maybe some are more equal than others. In an attempt to conceal other perpetrators the government and the party tend to consider the issue as a party affair. This led to the mere retirement of $\mathrm{Mr}$ Raphael Ige (for he was due for retirement) Chief Chris Uba was expelled and a move to expel others from the party as well as relieved them of their position and office... the 'punishment' meted out is quite inadequate as well as unwise and tends to lessen the magnitude of their offence and at the same time cover up other accomplices. This cannot in any way serve as a deterrent to others who have the same intention to carry out the same operation in future.....(August 9, 2003, page 12)

The paper, however, went beyond the boundaries of criticism to display emotional sentiments by harping more on the possible sanction 
Citation: Popoola M (2014) Public(s): Journalistic Slanting Of the Governor Chris Ngige and Chris Uba Prebendal Political Conflict in South-Eastern Nigeria, 2004-2006. J Mass Communicat Journalism 4: 218. doi:10.4172/2165-7912.1000218

for Ngige. Following this publication, another story was published that apparently disagreed with the above:

\section{Ngige abduction: ANSG will not prosecute UBA, others}

The Anambra State Government yesterday said that it would not pursue the prosecution of Chief Chris Uba and others who participated in the abduction of the state governor, Dr Chris Ngige and would jeopardize the cases filed in respect of the abduction.....(August 13, 2003, page 2)

This coverage is unhelpful as it tended toward escalation rather than de - escalation of the conflict. The reporting concentrated more on negativity, flouting the tenets of socially responsible and development oriented media. This reportage portrays Daily Trust more as a pessimist or even biased observer rather than as a "peace medium" as advocated by many important stakeholders in recent times. More conflict inciting stories were published by the newspaper:

\section{Police withdraw Ngige's security}

Policemen assigned to guard Governor Chris Ngige's office at Government House, Awka and his residence..... were withdrawn yesterday on the orders of the Inspector General of Police..... Governor Chris Ngige had however, in a broadcast to the people of Anambra State on Monday, described the attitude adopted by the Nigerian police in handling the political crisis in the state as unfair... He recalled that after the July 10, 2003 incident, an Awka high court ordered the arrest of Chief Chris Uba and his followers but the police ignored the order and said that the police authorities knew that the Enugu High Court order could be appealed..........(January 7, 2004, front page)

Ngige's complaint found expression in this story as he made veiled references to what would have happened if Uba were in his shoes, claiming that the police were unfair in treating him as such. This is another example of irresponsible and biased reporting which was capable of arousing sentiment, and indeed, inciting conflict.

\section{Lawyer explains why anambra crisis persists}

Human rights activist and Lagos lawyer, Barrister Festus Keyamo has blamed the failure to prosecute Chris Uba bad his accomplices as the reason behind the lingering political crisis in Anambra. Speaking on a radio programme, "view point", in Lagos over the weekend, Barrister Keyamo said that failure to visit the full wrath of the law on Chris Uba and his accomplices were responsible for the recurrence of the crisis despite the several attempts to broker peace...(February 13, 2004, Page 34)

Just like the former example, the above extract from a news story published by the Daily Trust is an example of irresponsible reporting, and in fact, seems to be a deliberate attempt to stir up further viciousness in the already escalated conflict. It is worrisome that the excerpt above was used as the lead paragraph (the first and most important part of the body of the news story) in order to drive home the conflicting point. The reportage below worsened the matter:

\section{No tears for Ngige}

The recent political logjam in Anambra State requires a more critical examination... Since the crisis erupted on July 10, 2003, there have been consistent attacks in the media against Chris Uba without Governor Chris Ngige being brought under the searchlight..... If Ngige were a man of honour and were conscious of the demand of the sensitive office as governor, he would never have had the shameless courage to tell the world that he signed away N3 billion belonging to the Anambra people under duress..... Uba and his spent their resources to give Ngige power. It is natural for them to expect some reward and gratitude from governor Ngige..... (August 7,2004, page 7)

This story is vilifying and was against the person of Ngige who has elicited more sympathy from the public on the issue of his abduction by Uba and his cohorts. It served to change the opinion of the public, create horror and angst. The writer was emotionally attached to the issue and carelessly presented his points in a manner that could have sparked up the conflict. To further escalate the situation, the paper published an opinion from another governor to boost the ego of Ngige and prompt him to take action against Uba and others thus propelling another inclination in the conflict.

\section{Kalu urges Ngige to prosecute UBA}

Abia State governor, Orji Uzor Kalu has berated Governor Chris Ngige of Anambra State over what he called his perpetual expectation from President Olusegun Obasanjo to take action on the abduction saga... He told newsmen that he was unsatisfied with the way the government is handling the Anambra crisis; saying Governor Ngige has the constitutional power to liaise with his Attorney-General and prosecute his political godfather, Chief Chris Uba and other conspirators. (Aug 8, 2004, page 19)

Subsequently, the crisis degenerated to a court case and this found expression in the story below. Apparently, the way the story was carried shows clearly, a bias by the paper which stated that the court "decides" to hear Uba, probably after a long wait as depicted below:

\section{Ngige: Court decides to hear UBA}

A Federal High Court in Abuja, yesterday dismissed a preliminary objection by Governor Chris Ngige of Anambra State, challenging its jurisdiction to hear a suit filed by Chief Chris Uba, seeking an order to stop his arrest and trial for treason over the abduction saga in Anambra State.... Uba also asked the court to set aside all processes, directives and orders from the defendants that would affect his life and liberties in as much as it concerns the crisis concerning the purported resignation of Dr. Ngige as Anambra State Governor.... (August 27, 2003, Page 2)

Newspaper: The Guardian: The abduction of Ngige which took place on July 10, 2003 was reported thus in The Guardian:

\section{Political crisis rocks anambra}

Anambra State's political leadership was yesterday thrown into turmoil with contradictory claims issuing from the governor, $\mathrm{Dr}$ Chris Ngige, his deputy Dr. Okechukwu Udeh, and the State House of Assembly.... (July 11, 2003, front page)

The term 'political crisis' seems harmless but laden with violence which might have caused panic and aggravated the situation to the extent of pointing accusing fingers to certain people as masterminds of the act as conflict was brewing. The following day, Uba who was accused as one of the masterminds of abduction of the governor dispelled the statement made in a different story that he demanded \#3billion from Ngige as payment of the election expenses used in installing him as governor and it was published thus:

\section{UBA denies demanding N3billion from Ngige}

As the controversy over the kidnap of Anambra State governor, Chris Ngige, the alleged mastermind of the act, Chief Chris Uba has denied demanding N3billiom from the governor to offset the money he spent for Ngige's election. Uba who spoke to reporters in Enugu yesterday described allegations that he asked for the refund of $N 3$ billion as cheap blackmail.... (July 12, 2003, front page) 
Casting headlines which shows outright outbursts from a conflicting party to the other usually has vitriolic consequences with effects that are left unimagined.

\section{NBA demands trial of Ngige's abductors, others}

To the Nigerian Bar Association (NBA), the episode surrounding last Thursday's abduction of the Anambra State Governor, Dr. Chris Ngige, should not be treated as a 'family affair' within the ruling People's Democratic Party (PDP). Rather, the incident should be thoroughly investigated and the perpetrators appropriately sanctioned... (July 15, 2003, front page)

In the midst of the tensed political atmosphere in the state, the NBA advocated that those behind the ordeal of Ngige and his abductors be sanctioned and that the case should not be treated as a family affair which the People's Democratic Party was advocating. This publication unshielded the conflicting parties from the public and the publication rather than abate the conflictual situation. It sought to influence and frustrate peace moves that could have prevented a full blown state crisis emanating from the prebendal political conflict.

\section{UBA, others show tapes of Ngige's 'resignation'}

The crisis surrounding the abduction and attempt to remove from office of the Anambra State Governor, Chris Ngige heightened in dramatic tenor yesterday with key characters in the saga presenting heaps of documents and video tapes as evidence that Ngige had actually resigned several times even before he was ever sworn in as Governor.....( July 18, 2003, Front Page)

This dramatic twist prompted the reportage below:

Anambra: Godfathers, godsons, voodoo men and the quest for power

There is no doubt that Chief Chris Uba believes in God. At the opening of his palatial home in Enugu State in May 2002, one of those he invited was a Bishop of the Anglican Communion, Ude. Ostensibly, the Bishop who prayed at the cutting of the cake had come to ask God to continue to bless the very rich 38-year-old father of six girls, and the house he built. The governor, a Christian too, said he quickly got in touch with his own Archbishop. It is not certain what the Bishop told him, but the governor said he went to the shrine armed with his Bible and Holy oil. They had taken him to the shrine to swear to an oath that would bind him to the whims and caprices of his benefactors, who had donated millions of naira and lent moral support... (July 21, 2003, Page 8)

This story was written in a tone which speaks of mockery and actually likened the conflicting parties to birds of a feather. This advanced the conflict as the public was served with more conflict inciting stories and statements attributed to politicians and stakeholders:

\section{UBA admits being fooled, insists on Ngige's ouster}

It would have been amusing if its consequences had not threatened Nigeria's democracy. But the treason in Anambra State took a comical turn, when the Chris Uba, the man at the centre of the July 10, 2003 abduction and attempt to remove Anambra State Governor Chris Ngige, insisted that his purported pact with the embattled governor super ceded the latter's electoral mandate.....The Chieftain of the People's Democratic Party (PDP) who has been recommended for dismissal by the party's national executive, also lamented his 'investment' in Ngige was a waste, wondering aloud why he did not vie for the office himself..... .Uba, however, said he remained resolute that Ngige must immediately leave the Government House, Awka, and expressed readiness to face trial if his actions so far are truly illegal... (July 22, 2003, front page)

Uba, in the above story, admitted been deceived and still insisted on Ngige's removal as governor of the State. It was not only Uba that had a grouse against Ngige. But being the principal attacker, the paper always put him at the forefront of the conflict while others who participated in the abduction were de- emphasized. This no doubt, tended to put the duo in a boxing ring constructed for them to engage in the battle of their lives. In celebrating these vehement outbursts, the conflict did not abate, it rather heightened and Anambra State was on fire as a result of the conflict.

\section{Last life of a cat}

There appears to be no correlation between his size and his heart. Dr. Chris Nwabueze Ngige, the troubled governor of Anambra State perhaps has the body of a rat but the heart of a lion. He is the unrelenting political gadfly that has kept all his enemies continually infuriated. They include his own party......... and one Chief Chris Uba.......... (August 21, 2005, page 36)

Perhaps in support of Ngige's travails and how he had been able to tackle them while still governing the State, the paper published the above story to give comfort to Ngige. The story served to support Ngige and how he had been able to cope with the deteriorating relationship between himself and his sponsors thereby portraying pure and undiluted bias for him as against Uba who was seen and regarded as a thorn in the flesh of Ngige. The story served to praise the perseverance of Ngige and has elements that might have escalated the situation.

\section{Newspaper:}

The Punch: Following Ngige's abduction on July 10, the Daily Punch published a story that sought to do an exposition on the conflict but slighted Ngige in the report.

\section{Coup of the godfathers}

The embattled governor fingered his godfather, Chief Chris Uba, as the brain behind his ordeal. Ngige confessed that his godfather had been a pain in the neck since he took over governance... But what was Ngige's expectation when Uba was doling out big bucks to finance his campaign.... (July16, 2003, Page 10)

That Ngige confessed that Chris Uba had been a pain in the neck since he took over governance could have been edited. This was capable of further escalating the conflict situation. The newspaper did not take cognizance of this.

\section{UBA took me to a shrine-Ngige}

Embattled governor of Anambra State, Dr Chris Ngige, on Friday narrated how those behind his travails took him to a local shrine with the intention of making him to swear to an oath of allegiance to them---(July 19,2003, page 10)

\section{Ngige spits fire!--I'll deal with UBA, others}

Embattled Governor of Anambra State, Dr Chris Ngige on Friday spat fire, promising to deal ruthlessly with Chief Chris Uba and others behind his recent abduction if they fail to purge themselves of their sins. (July 20, 2003, Front page)

In the above excerpt, Ngige made his position on the issue known. The headline of this story was cast in 72 points and it tended to explain the vengeful action Ngige would take on Uba. The prominence given to this story made it all the more important. It portrayed explicitly the 
vituperations of the aggrieved party. It should have been played down at least. The naked use of violence-laden language as depicted in the above story, was obviously capable of fuelling the situation and creating a new battleground for supremacy between the two conflicting parties such that peace moves between the two were futile.

\section{Ngige rules out reconciliation with $U B A$, others}

The Governor of Anambra State, Dr Chris Ngige on Saturday denied being a party to any move to reconcile with Chief Chris Uba and others who conspired with the former Assistant Inspector General of Police, Raphael Ige to abduct him on July 10. ( Page 8, August 10, 2003)

Rather than analyzing the alternatives to transforming the conflict, this story served to convey the point of view of the aggrieved party thereby aggravating the conflict. A month after the abduction, the paper, probably to create panic and make the parties loyal to Uba happy, came out with the following story:

\section{Over a month after his abduction: Ngige still lives like a captive}

Anambra State Governor, Dr. Chris Ngige has not yet overcome the trauma he suffered when his political godfathers attempted to remove him from power on July 10... Since July 10 when he was abducted from his office by policemen led by Assistant Inspector General of Police. Mr. Rapheal Ige Gov. Chris Ngige, has lived the life of someone under captivity. He goes about with a complex web of human barricade as security... Ngige was ushered into the Federation Hall venue of the meeting at the Hotel Presidential, Enugu like a patient requiring emergency attention.... (August 31, 2003, page 35)

This shows some elements of bias against Ngige as a follow up to the abduction. The general picture of insecurity painted here could have generated panic. This story is not also balanced as the other party's view was not mentioned. In another dimension to the conflict, The Punch reported thus:

\section{Ngige stops remission of money to UBA's account}

Anambra State Governor, Dr. Chris Ngige, has said that he had ordered the stoppage of direct remission of funds from the state's share of the Federation account to fund the projects being executed by his estranged godfather, Chief Chris Uba. (13 November, 2003, Page 21)

Perhaps, the aftermath of this reportage culminated into this conflict which was recklessly described by The Punch in a front page story.

\section{Gun battle as Ngige, UBA's supporters clash..... at PDP congress}

Sporadic gunshots and fisticuffs on Saturday disrupted the Southeast Zonal congress of the People's Democratic Party (PDP) held at the Micheal Okpara Square in Enugu as Governor Chris Ngige of Anambra State and his erstwhile godfather, Chief Chris Uba, engaged in a raw show of power. Thugs and armed policemen had a field day as they whipped, slapped, boxed and kicked their hapless victims freely.....The atmosphere immediately became charged. Uba moved towards the state box but was stopped by Ngige's details (Emphasizing the conflict, in the same story), Ngige's supporters pounced on the supporters of Uba, who missed their vehicles..... (December 7, 2003, page 41)

This reportage adopted an impressionistic style that gave a naked description of violence. It was obviously capable of aggravating a sense of panic among the reading public and this process of stimulating this panic eventually culminated into controversies without proposals for resolution of the conflict.

\section{Discussion of Findings}

\section{Research question 1}

How did selected newspapers slant the reportage of the conflict?: The newspapers slanted the reportage of the conflict with partisanship and incitement that escalated the conflict to violence, civil disorder and destruction of lives and properties in Anambra State within the study period. Prior to the conflict, the newspapers have even characterized Ngige and Uba as influential prebendary personalities, and this characterization culminated into the status assumption of the duo as godson and godfather respectively. When examined from the perspective of the influence the mass media have on the attitude and perception of their audience, the undue emphasis on political formidability of Uba by the newspapers certainly provided an attitudinal and behavioural structure within which the public could have reacted to the conflict and the violence that accompanied it. There was no significant effort directed by the newspapers at reconciling the conflicting parties; the newspapers even predicted the violence and the consequent calamitous consequences of the conflict, thus setting unconstructive agenda for the public. The manner in which the newspapers reported the conflicting parties and their utterances was conflict-provocative and at best inciting. Many of the analyzed latent and manifest contents confirm the strong relationship between the contents of the selected newspapers and public violence that accompanied the conflict.

\section{Research question 2}

To what extent was the slanting in adherence to the tenets of a socially responsible press?: The slanting of the reportage violates the principle of a socially responsible press. The reportage reflected incitement, partisanship and bias on the part of the newspapers. The social responsibility theory of the press holds inter alia, that, in reporting political conflicts in social political systems, the press is expected to raise conflict to a plane of discussion, but with proposals for resolution of the conflicts. However, the ways the Ngige and Uba prebendal conflict reportage were slanted could not have helped in reconciling the conflicting parties, but fuelled the conflicts to violence and public unrest. The reckless mode of reporting the conflict by the newspapers shows somewhat affiliation to conflicting parties during the period of study, and this prevented the newspapers from giving thought to how the conflicts could be resolved and how governance in Anambra State that was thwarted could be forestalled.

\section{Conclusion}

All the selected newspapers slanted their reportage of the prebendal political conflict, between former Governor Chris Ngige and Chris Uba in Anambra State Nigeria, in ways that escalated the conflict to civil disorder from 2003 to 2006 . The reportage showed incitement, partisanship, bias of the newspapers; and therefore the reportage violates the canons of social responsibility of the press. Conflict by the newspapers shows affiliation to conflicting parties during the study period, and this prevented the newspapers from giving thought to how the conflicts could be resolved and how governance in Anambra State that was thwarted could be forestalled. Conflicting parties and their utterances are conflict-provocative and at best inciting. Many of the analyzed latent and manifest contents confirm the strong relationship between the contents of the selected newspapers and public violence that accompanied the conflict.

\section{References}

1. Joseph R (1987) Democracy and Prebendal Politics in Nigeria: The Rise and fall of the Second Republic. Spectrum Books. 
Citation: Popoola M (2014) Public(s): Journalistic Slanting Of the Governor Chris Ngige and Chris Uba Prebendal Political Conflict in South-Eastern Nigeria, 2004-2006. J Mass Communicat Journalism 4: 218. doi:10.4172/2165-7912.1000218

Page 10 of 10

2. Corruption Perceptions Index Report 2006.

3. Dike, Victor E (2006) Nigeria: Governance and Nigeria's Ailing Economy. Daily Champion (Lagos)

4. Albert 10 (2005) Explaining Godfatherism in Nigerian Politics. African Sociological Review 9: 79-105.

5. Omu, Oboh (2008) Mass Media in Nigerian Democracy. Stirling Horden Publishers.

6. Awowede O (2003) Godfather Gangsters. Insider Weekly.

7. Akin W (2005) Political Godfatherism: Caging Lamidi Adedibu.
8. Okoli C (2007) The Godfatherism Phenomenon.

9. Ajayi F (2007) Nigerian Political Godfatherism in the World of Baale Molete. Nigeria World.

10. Adeoye A (2005) Godfatherism and the Future of Nigerian Democracy. African Sociological Review.

11. Popoola BO (2012) Newspaper Reportage of Personality-Induced Political Conflicts in Nigeria 1999-2009, an Unpublished PhD Seminar, presented to the Peace and Conflict Studies Programme, Insitute of African Studies, University of Ibadan, Nigeria.

12. Okereke (2005) Political Godfatherism and Democracy in Nigeria. 